\title{
Vitality and Endangerment of Contemporary Kurukh
}

\author{
Alisha Vandana Lakra ${ }^{1} \&$ Md. Mojibur Rahman ${ }^{2}$ \\ ${ }^{1}$ Senior Research Fellow, Department of Humanities and Social Sciences, Indian Institute of \\ Technology (Indian School of Mines), Dhanbad-826004 (Jharkhand) India. ORCID ID oooo- \\ ooo2-6707-6849 \\ Email: alisha.2013dro22o@hss.ism.ac.in \\ ${ }^{2}$ Associate Professor, Department of Humanities and Social Sciences, Indian Institute of \\ Technology (Indian School of Mines), Dhanbad-826004 (Jharkhand) India. ORCID ID oooo- \\ 0002-8454-0981
}

Received May 31, 2017; Revised July 24, 2017; Accepted July 27, 2017; Published August 18, 2017.

\begin{abstract}
A multilingual society shares some common social and cultural situations affecting the linguistic features of a language. It eventually appears in linguistic performances of the speech community which might lead to its endangerment. The Kurukh language, spoken in and around the district of Ranchi in Jharkhand, India, appears in a multilingual society where it is constantly affected by its neighbouring and dominant languages. The restricted use of the language has led to its endangerment. This paper describes the degree of endangerment of the Kurukh language and also assesses its vitality with reference to the factors proposed by UNESCO. The study investigates the speech performances of the speakers of Kurukh to assess the extent of code-mixing.
\end{abstract}

Keywords: Endangerment, Kurukh, code-mixing.

\section{Introduction}

In India, there are six distinct language families which are spoken by millions. They are Indo Aryan, Dravidian, Iranian, Nuristani, Austro - Asiatic and Tibeto - Burman language families. There are approximately more than 1600 languages spoken in India at present, out of which the government has recognized only 122 as the scheduled/official languages.(Abbi, 2012). Out of the 122 scheduled languages, 14 are Indo- Aryan, 4 are Dravidian, and the rest are Tibeto- Burman, and Austro -Asiatic languages. Among the present 122 scheduled languages of India, 88 are tribal languages and still, there are many tribal languages which are not recognized by the government of India. (Benedikter, 2009).

Bhadriraju Krishnamurti, in 1961, geographically classified the Dravidian languages into Central, South and North Dravidian. He was the first to suggest the name North Dravidian for an ethnic group of Kurukh, Malto, and Brahui. In 1970, Andronov further sub- categorized the North Dravidian languages in which he kept Kurukh and Malto under north- eastern and Brahui under north-western.

Kurukh is a North Dravidian language of the Oraon tribe which is spoken by approximately two millions people of the Chotanagpur plateau of the East-Central India. It is

(C) AesthetixMS 2016. This Open Access article is published under a Creative Commons Attribution Non-Commercial 4.0 International License (http://creativecommons.org/licenses/by-nc/4.o/), which permits non-commercial re-use, distribution, and reproduction in any medium, provided the original work is properly cited. For citation use the DOI. For commercial re-use, please contact editor@rupkatha.com. 
spoken in Jharkhand, Bihar, Assam, West Bengal, Orissa, Tripura (Ethnologue: Languages of the World, 20o1 Census). The tribe was not native to the land before they entered Chotanagpur plateau. There have been speculations about their origin and their migration paths.

\section{Historiographical mapping of Kurukh}

\section{Origin}

The scholars have three different opinions about the origin of Kurukh which is spoken in Jharkhand (specifically Ranchi and its neighbouring villages). (Tirkey, 20-22)

\section{South and South- East India}

According to S. C. Roy, Kurukh speakers might have come from Coorg, a small place in South India. Some of the scholars hold the views of their entrance from the South-East Asia.

\section{Gujarat}

Elefenbein, in 1987, proposed Bloch's hypothesis, according to which the Brahui tribe migrated from Baluchistan (area of the Indus Valley) in different directions. The three tribes moved towards the south- east from Baluchistan of Pakistan. The fourth tribe went to Sindh which is the province of Pakistan where the tribe still speaks Brahui. One of the tribes which went to the south- east, further split into two groups at Rohtasgarh in Bihar. After the splitting, one group went to the Rajmahal Hills in Santhal Pargana and the other went to the Chotanagpur plateau where Kurukh is spoken (Kurukh World).

Joseph Elegenbein is of the opinion that the Kurukh/ Kurux (Oraons) and the Malto tribes earlier came from the north- west direction and settled around the river Narmada near

Baruch in Gujarat and later moved via Ujjain to Rohtasgarh, while the Brahui went to Baluchistan in the Western direction. (Tirkey, 2013)

\section{Harappa}

The Indus Valley Civilization is also known as Harappan civilization. Before 2500 B.C., the Oraons lived near the Indus Valley and they lived a sophisticated life there. The valley was consistently destroyed by flood and diseases and the climate became dry. It is also believed that the Oraons were attacked by the Aryans and were forced to leave the place. They have migrated in 2500 B.C. to the north- east and the south- west region from Baluchistan. (Tirkey, 21-22)

\section{Migration Paths}

In 1927, according to Grinard, Oraon and Maler occupied the land between the rivers Ghagra, Tons in the south-west and Sone River in Bihar. The Oraons were removed from the erstwhile Shahabad district of Bihar and then they fled to the north at Haridwar in Uttar Pradesh. After that, they joined the Aryan army of the Kauravas against the Pandavas. They were defeated by the Pandavas and moved towards the South India. They passed through the forest of Brindavan on the bank of river Yamuna and settled in the place called Pipripat in Gujarat. They again moved to the Rohtasgarh and built a fort there and lived there for many years. After that, they were defeated in a battle against the Mughals and were forced to leave the Fort (Mishra,n.d.). The Oraons then took shelter in the Chotanagpur plateau and since then they have been living with the other ethnic tribal groups of the plateau. 


\section{Settlement in the Chotanagpur Plateau}

The central and western parts of the Ranchi district are generally described as the Chotanagpur. The plateau consists of the two levels of the elevation of 2000 feet and 1000 feet above sea level. The upper plateau covers about the two- third of the district area and comprises of its northern, central, and western parts (Roy, 38-39).

The betrayal at the hands of the milkmaid led to the reoccurrence of the attack to which it caused the dislodgement of the tribe from Rohtasgarh. After the defeat, the tribe entered the Plateau and took shelter (Tirkey).

\section{Demographic distribution, population, and works on Kurukh language}

The tribe is residing in Ranchi district of Jharkhand, Madhya Pradesh, Orissa, Bihar, Chattisgarh, Assam, Tripura, and Andaman. The present population of the tribe is approximately two million (Census 2001, Ethnologue: Languages of the World).

Works on the Kurukh language:

i. Brief Grammar and Vocabulary of the Oraon Language by Rev. F. Batsch, 1866

ii. Kurukh (Oraon)- English Dictionary by Ferdinand Hahn, 1903

iii. Kurukh Grammar by Ferdinand Hahn, 1911

iv. A Grammar of the Oraon Language by A. Grinard, 1924

v. An Oraon - English Dictionary by A. Grinard, 1924

vi. Introduction of Kurukh Script 'Tolong Siki' by Narayan Oraon

vii. Establishment of Kurukh Literary Society

\section{Distinctive features of the Kurukh Language in brief:}

i. Kurukh, like other Dravidian languages, is an agglutinative language

ii. The sentence structure is subject+object+verb (SOV)

iii. In its morphological construction, there is suffixation, there is no infix or prefix to the language

iv. Vowel nasalization is a contrastive and distinctive feature

v. Retroflection is also a key feature of the language

\section{Endangerment}

A language is endangered when it heads towards its extinction or which is likely to become extinct in the coming years. To count the degree of endangerment of a language, there are proposed factors, on the scale of various levels where a language can be found in the true state of its existence. A language is endangered when the speakers of the language cease to use their language, use it in progressively restricted communicative domains, and stops the intergenerational transfer of their language (Language Vitality and Endangerment, UNESCO). The intergenerational transfer is important for the sustainability of a language, and where there is no intergenerational transfer, the language, even after the strength of the community members, appears to be in danger. 


\section{Objective of the Study}

The main objective of the study is:

i. To describe the endangerment of Kurukh language spoken in and around Ranchi.

ii. To assess its vitality with the factors proposed by UNESCO.

iii. To study the consistent pattern of code-mixing of the community speakers.

\section{Methodology}

\section{Rationality in Oraon and their language}

According to UNESCO's 'Atlas of Endangered Languages', Kurukh is a vulnerable language. The tribe appears in a multilingual setting with other major tribes, and for this reason, their language is constantly getting affected by its neighbouring languages. To determine the endangerment of the language in its social context, an investigation of the linguistic behaviour of the members of the language community presents a picture where the Kurukh Mother Tongue is vulnerable.

The total population of the Oraon Community in Ranchi, from a different religion, and environs, according to the 2011 census:

Census 2011: State-wise list of STs (Oraon) with details in terms of Households, Population (Total, Male, Female), sex ratio, child sex ratio, Literacy (Total, Male, Female)

\begin{tabular}{|c|c|c|c|c|c|c|c|c|c|c|c|}
\hline \multirow{3}{*}{$\begin{array}{l}\text { Stat } \\
\text { e } \\
\text { code }\end{array}$} & \multirow{3}{*}{$\begin{array}{l}\text { State } \\
\text { name }\end{array}$} & \multirow{3}{*}{$\begin{array}{l}\text { ST } \\
\text { name }\end{array}$} & \multirow{3}{*}{$\begin{array}{l}\text { Number } \\
\text { of } \\
\text { househol } \\
\text { ds }\end{array}$} & \multicolumn{3}{|c|}{ Total population } & \multirow{3}{*}{$\begin{array}{l}\text { Sex } \\
\text { ratio }\end{array}$} & \multirow{3}{*}{$\begin{array}{l}\text { Child } \\
\text { sex } \\
\text { ratio }\end{array}$} & \multicolumn{3}{|c|}{ Literacy } \\
\hline & & & & & & & & & Total & Male & Female \\
\hline & & & & Total & Male & Female & & & & & \\
\hline 20 & $\begin{array}{l}\text { Jhark } \\
\text { hand }\end{array}$ & $\begin{array}{l}\text { Oraon, } \\
\text { Dhanga } \\
\text { r } \\
\text { (Oraon) }\end{array}$ & $3,24,826$ & $17,16,618$ & $\begin{array}{l}8,55,21 \\
0\end{array}$ & $8,61,408$ & 1007 & 967 & 67.0 & $75 \cdot 9$ & 58.1 \\
\hline
\end{tabular}

(Statistical Profile of ST in India 2013, Ministry of Tribal Affairs)

\section{Selection of Field site:}

Oraon is one of the major tribe of Chotanagpur Plateau. The researcher has collected data from the members of the community living in Ranchi and in the adjacent villages where Kurukh is spoken. The tribe is mainly found in Ranchi, Gumla, Kadge, Mandar, Itki. The survey was conducted in Kurukh speaking belt of the state, specifically Ranchi and its nearby villages.

\section{Selection of Respondents:}

The main focus of the researcher was to collect data from all the age groups and from the different gender of the community.To cover the variation in their speech, the researcher reached to the urban and the rural areas of Ranchi district where the speech community lives. 


\section{Total Sample size:}

For the present study, the researcher has collected data from 80 speakers of different genders, age groups, location, and domain. The total sample size involves 80 speakers, out of which 40 were urban speakers and 40 were rural.The equal sample size of urban and rural speakers helped to maintain the accuracy of the study.

\section{Tools and Technique of Data Collection}

To record the data and the speech of the language community, voice recorder of HTC $816 \mathrm{~g}$ phone was used. The techniques employed by the researcher to carry out the study involved narration method, direct communication (interview, elicitation method), and observation method. The questionnaires and the recorded data was further studied for the above-mentioned objectives. The details of the selected participants are listed below:

\begin{tabular}{|c|c|c|c|c|c|c|c|c|}
\hline \multirow[t]{2}{*}{ Participants } & \multirow{2}{*}{$\begin{array}{c}\text { Children } \\
\& \\
\text { Teenagers } \\
(5-17)\end{array}$} & \multirow{2}{*}{$\begin{array}{l}\text { Adult } \\
(18-45)\end{array}$} & \multirow{2}{*}{$\begin{array}{c}\text { Elderly } \\
\text { (Above 45) }\end{array}$} & \multicolumn{2}{|c|}{ Gender } & \multirow[t]{2}{*}{ Occupation } & \multirow{2}{*}{$\begin{array}{l}\text { Urban/Rural } \\
\text { Social space }\end{array}$} & \multirow{2}{*}{$\begin{array}{l}\text { Educational } \\
\text { qualification }\end{array}$} \\
\hline & & & & M & F & & & \\
\hline Participant 1 & & & * & * & & Farmer & Rural & Uneducated \\
\hline Participant 2 & & * & & & * & Student & Rural & $12^{\text {th }}$ std. \\
\hline Participant 3 & & * & & & * & Student & Urban & $12^{\text {th }} \mathrm{std}$. \\
\hline Participant 4 & & & * & & * & Housewife & Rural & Matriculate \\
\hline Participant 5 & & * & & & * & Housewife & Urban & Intermediate \\
\hline Participant 6 & & & * & & * & Retired officer & Rural & Intermediate \\
\hline Participant 7 & & & * & * & & Church Officer & Urban & Intermediate \\
\hline Participant 8 & & * & & * & & Employee & Urban & Intermediate \\
\hline Participant 9 & & & * & * & & Professor & Rural & Master \\
\hline $\begin{array}{c}\text { Participant } \\
10\end{array}$ & & * & & * & & Employee & Urban & Graduate \\
\hline Participant 11 & & & * & & * & Housewife & Urban & Matriculate \\
\hline $\begin{array}{c}\text { Participant } \\
12\end{array}$ & * & & & * & & Student & Urban & $8^{\text {th }}$ std. \\
\hline $\begin{array}{c}\text { Participant } \\
13\end{array}$ & * & & & * & & $\begin{array}{l}\text { Student/ } \\
\text { labourer }\end{array}$ & Rural & $6^{\text {th }}$ std. \\
\hline $\begin{array}{c}\text { Participant } \\
14\end{array}$ & & * & & & * & Employee & Urban & Graduate \\
\hline
\end{tabular}




\begin{tabular}{|c|c|c|c|c|c|c|c|c|}
\hline $\begin{array}{c}\text { Participant } \\
15\end{array}$ & & & * & & * & Employee & Rural & Intermediate \\
\hline $\begin{array}{c}\text { Participant } \\
16\end{array}$ & & * & & * & & Worker & Rural & $3^{\text {rd }} \mathrm{std}$ \\
\hline $\begin{array}{c}\text { Participant } \\
17\end{array}$ & * & & & & * & Student & Rural & $6^{\text {th }}$ std. \\
\hline $\begin{array}{c}\text { Participant } \\
18\end{array}$ & * & & & & * & Student & Rural & $7^{\text {th }}$ std. \\
\hline $\begin{array}{c}\text { Participant } \\
19\end{array}$ & & * & & & * & Housewife & Rural & Intermediate \\
\hline $\begin{array}{c}\text { Participant } \\
20\end{array}$ & & & * & * & & Professor & Urban & Master \\
\hline
\end{tabular}

Fig.1. List of Participants.

The data was collected was collected from the 80 speakers of the speech community. Some selected participants have been mentioned above on the basis of the quality of recordings and variations. The 80 participants showed the prominent linguistic variations of Kurukh in their speech. The participants were stratified on the basis of their age, gender, educational qualification, occupation and on their urban and rural social space.

\section{Kurukh's Vulnerability}

The UNESCO provides an 'Atlas of Endangered Languages' which gives a full list of world's languages with detailed description on their degree of endangerment. UNESCO's report of the Kurukh language by the degree of endangerment is:

\begin{tabular}{|l|l|l|}
\hline Name of the language & Number of speakers & Degree of endangerment \\
\hline Kurux (Kurukh), India & 1751489 & Vulnerable \\
\hline
\end{tabular}

\section{The proposed nine factors by UNESCO to measure the degree of endangerment:}

Factor 1. Intergenerational language transmission

In the evaluation of the vitality of a language, the factor of intergenerational language transmission plays a vital role. This factor helps in evaluating the transmission of the language from one generation to the other. It provides the different degree of endangerment from 'safe' to 'extinct' and counts the grade on the scale from ' 5 ' to 'o' depending on the usage of speakers of all generation.

\begin{tabular}{|l|l|l|}
\hline Degree of Endangerment & Grade & Speaker Population \\
\hline Safe & 5 & The language is used by all ages, from children up. \\
\hline
\end{tabular}




\begin{tabular}{|l|l|l|}
\hline Unsafe & 4 & $\begin{array}{l}\text { The language is used by some children in all domains; it is used } \\
\text { by all children in limited domains. }\end{array}$ \\
\hline Definitely endangered & 3 & The language is used mostly by the parental generation and up. \\
\hline Severely endangered & 2 & $\begin{array}{l}\text { The language is used mostly by the grandparental generation and } \\
\text { up. }\end{array}$ \\
\hline Critically Endangered & 1 & $\begin{array}{l}\text { The language is used mostly by very few speakers, of great- } \\
\text { grandparental generation. }\end{array}$ \\
\hline Extinct & 0 & \begin{tabular}{l} 
There exists no speaker. \\
\hline
\end{tabular}
\end{tabular}

UNESCO, Language Vitality and Endangerment, 2003

The Kurukh language's degree of endangerment is 'vulnerable, where UNESCO describes vulnerability as 'Most children speak the language, but it may be restricted to certain domains. Example, home'. (Atlas of the World's Languages in Danger, UNESCO project).

According to the researcher's observation of the community living in urban areas, it can be said that the proficiency in Kurukh as a mother tongue is not successfully transferred to the future generation. It is the heritage which has to be passed on from one generation to another. It is the cultural uniqueness or the social identity, which defines a group and distinguishes it from other ethnic groups, years after years.

Kurukh exists in a multilingual society where Hindi (after the establishment of Jharkhand as a separate state and Ranchi became its capital city) became the dominant language. Another important amalgam of the Kurukh community is with the other tribes of Ranchi. The tribes together celebrate Sarhul festival, the spring festival of the Chotanagpur Plateau. These language ideologies, which occur in every environment, affect the other ethnic minority languages. Ideologies of a dominant language can be

a. Their cultural ideologies which are adopted by several other minority languages by the dominance of the major one.

b. Their history can also affect in tracing the history of the minor groups. (recorded history)

c. Their written documents like grammar, Vedas, script, stories etc. influence the minority languages.

Factor 2. An absolute number of speakers.

Endangerment of a language is also defined by its absolute number of speakers. A speech community should have a large or fair number of speakers. If a speech group is very small then it is definitely at risk and is in danger. For example, if a small speech group is attacked by any catastrophes, diseases, or any natural calamity, the entire community is at risk (Language Vitality and Endangerment, UNESCO).

According to UNESCO, a language is more vulnerable when its speakers are attacked by disease, natural disaster (the speculation of Harappan origination of Kurukh, when the tribe was constantly destroyed by flood and then the diseases), Warfare (dislodgement of Oraons by the Mughals from Rohtasgarh Fort). The tribe took shelter in the plateau and gradually started to merge the cultural and linguistic features of the neighbouring tribes. 
The strength of the Oraon tribe (speakers of Kurukh) is approximately two million, but very few of them speak their own mother tongue in every domain; some of them use it in their restricted domain and most of them who belong to urban areas are adopting the culture and languages of the other dominant languages.

Factor 3. The proportion of speakers within the total population.

\begin{tabular}{|l|l|l|}
\hline Degree of Endangerment & Grade & $\begin{array}{l}\text { The proportion of speakers } \\
\text { within the total population. }\end{array}$ \\
\hline Safe & 5 & All speak the language. \\
\hline Unsafe & 4 & Nearly all speak the language. \\
\hline Definitely endangered & 3 & A majority speak the language. \\
\hline Severely endangered & 2 & A minority speak the language. \\
\hline Critically endangered & 1 & Very few speak the language. \\
\hline Extinct & 0 & None speak the language. \\
\hline
\end{tabular}

UNESCO, Language Vitality and Endangerment, 2003

In evaluating the vitality of a language the factor of the proportion of the speakers of it is essentially important. The factor provides the degree of endangerment from 'safe' to 'extinct' on the grade scale of ' 5 ' to 'o' on the proportion of speakers use the language.

In terms of Kurukh, the speakers in the urban area use the language in restricted domains, whereas, in the rural area the speakers are fairly more. The urban- rural factor affects the use of Kurukh language. According to Census 2011 and the UNESCO report, the number of Kurukh speakers is nearly two million. The strength of the speakers is high but the proportion of speakers is not 'safe'. According to the field survey conducted by the researcher, it is observed that nearly all the speakers speak their mother tongue (in the certain restricted domain and limited young speakers in an urban area).

Factor 4. Shift in domains of the use of language.

\begin{tabular}{|l|l|l|}
\hline Degree of endangerment & Grade & Domains and functions \\
\hline Universal use & 5 & $\begin{array}{l}\text { The language is used in all domains and for all } \\
\text { functions. }\end{array}$ \\
\hline Multilingual parity & 4 & $\begin{array}{l}\text { Two or more languages may be used in most } \\
\text { social domains and for most functions; the } \\
\text { ancestral language usually is rare in the public } \\
\text { domain. }\end{array}$ \\
\hline Dwindling domain & 3 & $\begin{array}{l}\text { The ancestral language is used in home } \\
\text { domains and for many functions, but the } \\
\text { dominant language begins to penetrate home } \\
\text { domains. }\end{array}$ \\
\hline Limited or formal domains & 2 & The language is used in limited social domains \\
\hline
\end{tabular}




\begin{tabular}{|l|l|l|}
\hline & & and for several functions. \\
\hline Highly limited domains & 1 & $\begin{array}{l}\text { The language is used only in very restricted } \\
\text { domains and for very few functions }\end{array}$ \\
\hline Extinct & 0 & The language is not used in any domain at all. \\
\hline
\end{tabular}

UNESCO, Language Vitality and Endangerment, 2003

This factor provides the degree of endangerment from 'universal use' to 'extinct' on the grade scale of ' 5 ' to 'o' and in the domains, it is used.

UNESCO states that multilingualism does not always lead to language loss. Kurukh coexists with other languages, where it is spoken in home domains and in social domains. The speakers of Kurukh use other languages in office domain and public domains. So, accordingly, Kurukh is placed on 'grade 4' as it is performed by the speakers among themselves, not with the other language groups. For the interaction with the other groups, they use Sadri or Hindi.

Factor 5. Response to new domains and media.

The proficiency of a speaker depends on his/her ability to read, to write or to speak the language. The language is practiced in different occasions and different domains. There are emerging new domains like newspaper, media (radio programs, television channels), code of conduct in schools, offices, internet etc.

\begin{tabular}{|l|l|l|}
\hline Degree of endangerment & Grade & $\begin{array}{l}\text { New Domains and Media Accepted by the } \\
\text { Endangered Language }\end{array}$ \\
\hline dynamic & 5 & The language is used in all the new domains. \\
\hline Robust/active & 4 & $\begin{array}{l}\text { The language is used in most of the new } \\
\text { domains. }\end{array}$ \\
\hline receptive & 3 & The language is used in many domains. \\
\hline copying & 2 & $\begin{array}{l}\text { The language is used in some of the new } \\
\text { domains. }\end{array}$ \\
\hline minimal & $\mathbf{O}$ & $\begin{array}{l}\text { The language is used only in a few of the new } \\
\text { domains. }\end{array}$ \\
\hline inactive & $\mathbf{0}$ & $\begin{array}{l}\text { The language is not used in any of the new } \\
\text { domains. }\end{array}$ \\
\hline
\end{tabular}

UNESCO, Language Vitality and Endangerment, 2003

Kurukh community is expanding their language into the emerging new domains which may increase the use of the language among the speakers. The new emerging domains are the medium of instructions in schools and colleges, official domain and broadcast media (including radio programs, television, and internet). After Narayan Oraon had devised the script 'Tolong Siki' for Kurukh (earlier the language was oral and later Devanagari script was used for it), it was introduced in some rural schools and colleges. Kurukh is taught in rural schools and colleges. Kurukh magazines are available in the market and there is a radio program in Kurukh.

Kurukh is robust/ active as it is used in most of the new domains.

Factor 6. Materials for Language Education.

The education in the respective language is very important for the vitality of that language. The dominant languages have their written documents, grammar, and a script which strengthen the language. The languages which have oral traditions should have language education to strengthen 
the languages well. Books and other needed materials should be provided for the accomplishment of this and, consequently, it will bring the social and economic strength to the community.

\begin{tabular}{|l|l|}
\hline Grade & Accessibility of Written Materials \\
\hline 5 & $\begin{array}{l}\text { There is an established orthography, literacy tradition with grammars, dictionaries, texts, } \\
\text { literature, and everyday media. Writing in the language is used in administration and } \\
\text { education. }\end{array}$ \\
\hline 4 & $\begin{array}{l}\text { Written materials exist, and at school, children are developing literacy in the language. } \\
\text { Writing in the language is not used in administration. }\end{array}$ \\
\hline 3 & $\begin{array}{l}\text { Written materials exist and children may be exposed to the written form at school. Literacy is } \\
\text { not promoted through print media. }\end{array}$ \\
\hline 2 & $\begin{array}{l}\text { Written materials exist, but they may only be useful for some members of the community; and } \\
\text { for others, they may have a symbolic significance. Literacy education in the language is not a } \\
\text { part of the school curriculum. }\end{array}$ \\
\hline $\mathbf{0}$ & $\begin{array}{l}\text { A practical orthography is known to the community and some material is being written. } \\
\text { No orthography is available to the community. }\end{array}$ \\
\hline
\end{tabular}

UNESCO, Language Vitality and Endangerment, 2003

Kurukh language is the most studied language by the scholars. This is evident through the researches and works that are done in this language. There are English- Oraon and OraonEnglish dictionaries, grammars, texts, and literature in this language; recently the language with its script has been introduced in rural schools and colleges. So, accordingly, Kurukh can be kept under the 'grade 4'as it has all the accessible materials but writing in Kurukh is not used in administration.

Factor7. Governmental and Institutional Language Attitudes and Policies, Including Official Status and Use

This factor describes the degree of the support of government from 'equal support' to 'prohibition' on the scale of ' 5 ' to 'o'. The support of the government could be supportive and differentiated for the language; passive assimilation, active assimilation and forced assimilation with the dominant language; and prohibition of the minority language.

This proposed factor is not clear in terms of Kurukh. According to the observation of the researcher, the language, on the basis of the strength of the tribe, is one of the dominant languages of the land, but, in terms of performance, it is a non- dominant language (the language used in private domains, no public interaction is done in the language). The usage of the language is prominently within the community speakers. India has a language policy for non-dominant languages but the state government is found to be inactive to encourage the use and preservation of the language.

\section{Factor 8. Community Members' Attitudes Towards Their Own Language}

The attitude of the community members towards their language is essential and vital, where most of the speakers value their language, where some have an indifferent and negative attitude towards their language. 


\begin{tabular}{|c|c|}
\hline Grade & Community Members' Attitudes toward Language \\
\hline 5 & All members value their language and wish to see it promoted. \\
\hline 4 & Most members support language maintenance. \\
\hline 3 & $\begin{array}{l}\text { Many members support language maintenance; others are indifferent or may even support } \\
\text { language loss. }\end{array}$ \\
\hline 2 & $\begin{array}{l}\text { Some members support language maintenance; others are indifferent or may even support } \\
\text { language loss. }\end{array}$ \\
\hline 1 & $\begin{array}{l}\text { Only a few members support language maintenance; others are indifferent or may even support } \\
\text { language loss. }\end{array}$ \\
\hline o & No one cares if the language is lost; all prefer to use a dominant language. \\
\hline
\end{tabular}

UNESCO, Language Vitality and Endangerment, 2003

Language attitude is one's belief and attitude towards its own language. The attitude of the speakers and non- speakers of the language helps to understand their views towards the particular language. Attitude is an important factor through which a language can be maintained or abandoned.

The members of the tribe are simple; they believe in peaceful survival; their major occupation is farming and agriculture. The primary concern of the tribe was food and living (Roy, n.d.).But, in the present day, the style of living has changed in the urban areas with the exposure of development and advancement of Ranchi and internet exposure. The speakers have changed Hindi as their preferable language and English has been the code of conduct in the urban areas.

\section{Factor 9: Amount and Quality of Documentation}

This factor evaluates the language over the existence of the documentation. There are dominant and major languages which have superlative, good, and fair documentation where the grammar and textbooks are available in the languages and some languages have fragmentary and inadequate documentation.

\begin{tabular}{|l|l|l|}
\hline $\begin{array}{l}\text { Nature of } \\
\text { Documentation }\end{array}$ & Grade & Language Documentation \\
\hline Superlative & 5 & $\begin{array}{l}\text { There are comprehensive grammars and dictionaries, extensive texts; a } \\
\text { constant flow of language materials. Abundant annotated high-quality audio } \\
\text { and video recordings exist. }\end{array}$ \\
\hline Good & 4 & $\begin{array}{l}\text { There are one good grammar and a number of adequate grammars, } \\
\text { dictionaries, texts, literature, and occasionally updated everyday media, } \\
\text { adequate annotated high-quality audio and video recordings. }\end{array}$ \\
\hline Fair & 3 & $\begin{array}{l}\text { There may be adequate grammar or sufficient amount of grammars, } \\
\text { dictionaries, and texts, but no everyday media; audio and video recordings } \\
\text { may exist in varying quality or degree of annotation. }\end{array}$ \\
\hline Fragmentary & $\mathbf{2}$ & $\begin{array}{l}\text { There are some grammatical sketches, word-lists, and texts useful for limited } \\
\text { linguistic research but with inadequate coverage. Audio and video recordings }\end{array}$ \\
\hline
\end{tabular}




\begin{tabular}{|l|l|l|}
\hline & & may exist in varying quality, with or without any annotation. \\
\hline Inadequate & 1 & $\begin{array}{l}\text { Only a few grammatical sketches, short word-lists, and fragmentary texts. } \\
\text { Audio and video recordings do not exist, or are of unusable quality, or are } \\
\text { completely un-annotated. }\end{array}$ \\
\hline
\end{tabular}

UNESCO, Language Vitality and Endangerment, 2003

The nature of documentation of Kurukh language can be termed as 'good' and 'fair', as there is a good grammar by Ferdinand Hahn, dictionaries, texts of literature, research papers on the Kurukh language but not every day updated media.

\section{The code mixing and code switching in contemporary Kurukh}

During the exploration of ethnolinguistic vitality in Kurukh, a consistent pattern of multilingual practice is witnessed. After Jharkhand declared as a separate state and Ranchi its capital city, the city has witnessed immense changes in last few years. These changes are not only occupational, economic or geographical, but changes are also seen through linguistic perspectives. Resided with other ethnic groups, the language has always in contact with other languages. The domain describes one's language of choice. The major domains in which code mixing and code switching are seen, are home domain, social domain.

The collected data were studied to evaluate the extent of code mixing and code switching found in the speech of the speakers whose mother tongue is Kurukh. The data was collected and stratified on the basis of urban- rural environs, age, and gender. The examples are as following:

i. i:d ta:la: parab toli: i:d bəsant hi: barna: avsar nu: məni: this nature festival is this spring of advent occasion on celebrate

This is nature's festival which is celebrated on the advent of spring season.

In this sentences, there are words like bəsant, parab, avsar which are Hindi words. parab is parv in Hindi and rustically it is spoken as parab in Sadri.

\begin{tabular}{|c|c|c|}
\hline $\begin{array}{l}\text { a:ge: } \\
\text { before }\end{array}$ & $\begin{array}{l}\operatorname{adigh}^{\text {it: }} \\
\text { it's }\end{array}$ & $\frac{\underline{\mathbf{d e}}: \mathbf{k}^{\mathbf{h}} \mathbf{b}^{\mathrm{h}} \mathbf{a}: \mathbf{l}}{\text { take care }}$ \\
\hline
\end{tabular}

Firstly it is taken care.

a:ge: is a Hindi word which can mean after, before, first. The sense and meaning of the sentence decide the exact usage of the word.

de: $\mathbf{k}^{\mathbf{h}} \mathbf{b}^{\mathbf{h}} \mathbf{a}:$ lis again a Hindi word.

iii. en akun rã:tfĩ: nu: pad $^{\mathrm{h}} \mathbf{a}: \mathbf{i}-\mathrm{n}$ a logen

$$
\text { I now Ranchi in study is doing }
$$

I am now studying in Ranchi.

The participant has used the word $\mathbf{p a d}^{\mathrm{h}} \mathbf{a}: \mathbf{i}$ which is a Hindi word. 
iv. hormampariva:r mil dzul ke daule se parab manandam all family together good with festival celebrate

All the family members nicely celebrate the festival together.

In this sentence, the participant has used words like pariva:r, mil, dzul, ke, se,parabwhich are Hindi words.

v. tgehra:nudai: ba;de nu: nasta: muk ${ }^{\mathrm{h}} \mathrm{ae}$

face wash after breakfast eat

Eat breakfast after washing your face.

The participant has used words like tfehra:,ba;de and nasta: which are either Hindi words or derivatives. For example, tfehra: and nasta: are Hindi words but ba;de is a Sadri word which is derived from the Hindi word $\mathbf{b a} ; \mathbf{d}_{\mathbf{i}}$

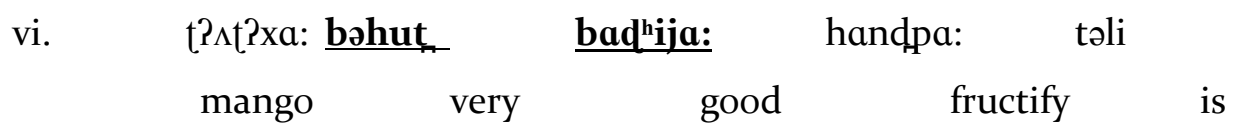

Very good (in quantity and quality) mangoes have fructified.

bəhut and badhija: are Hindi words which means very and good but in this sentence it is indicating at the quality and quantity of the fruit.

vii. t?ut?xa: nu: bəhut, sa:ra: gu:n rə-əi:

mango in very much quality is

In mangoes, there are so many qualities.

bəhut, sa:ra:,gu:n are Hindi words used by the participant in the utterance.

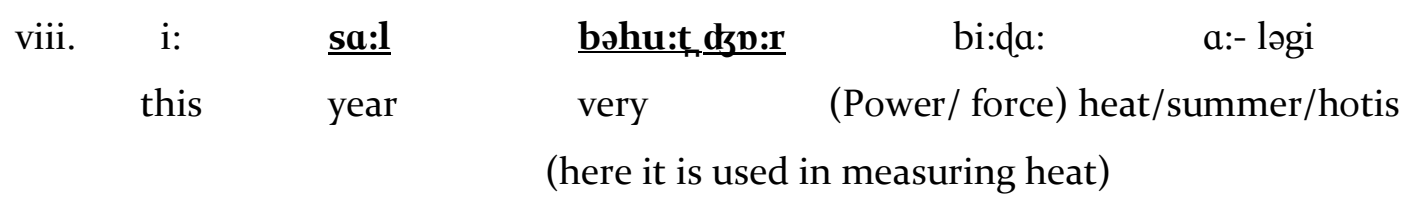

This year it is very (much) hot.

sa:l, bəhu:t, dzp:r are Hindi words which means year, very and power or force. But here, dyb:rdoes not indicate at power but it indicates at the hotness of the temperature.

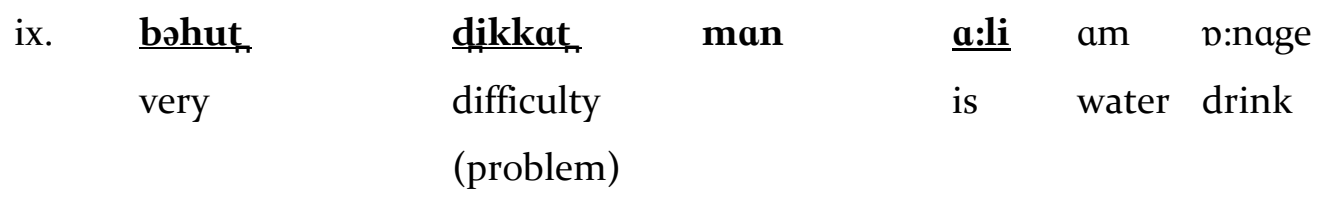

There is a lot of problem of drinking water. 
bəhut, dikkat, man,a:liare Hindi and Sadri words.manmeans allanda:limeans is and come.

The above examples show the code mixing and code switching which are evident and practiced in the speech of the Kurukh speakers. There is a lot of Hindi and Sadri (lingua franca) words which have mixed in the Kurukh language.

\subsection{Extend of code mixing}

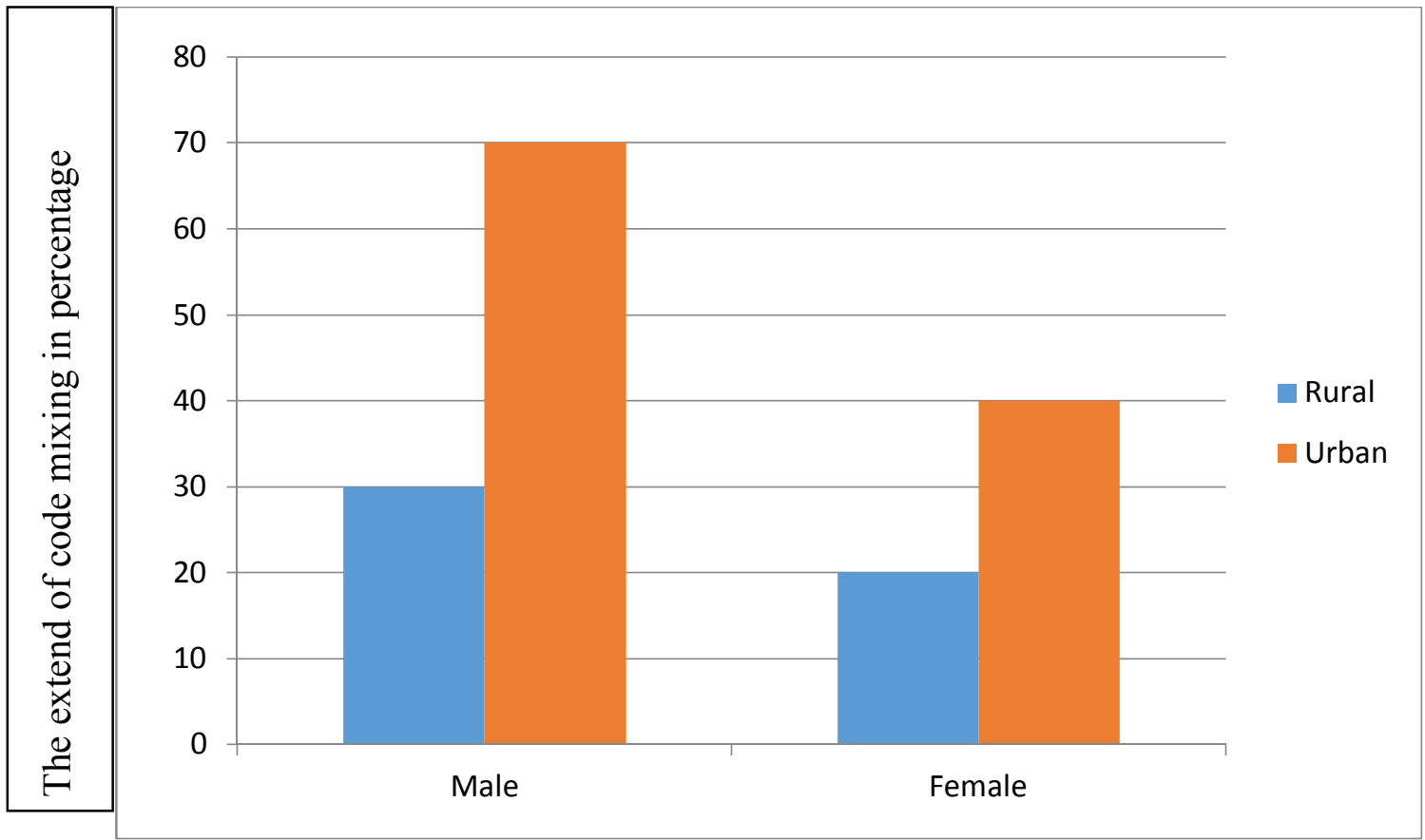

Fig. 2. The male and female speech performance in urban and rural social space

This graph presents the code mixing in the speech performances of men and women resided in urban and rural areas. The present Kurukh language is not spoken in a pure form by the speakers, it is often mixed with the words of Hindi, English. Munda and Sadri. The examples of code mixing by the speakers of the community show the influence of Hindi and Sadri upon the speech of the Kurukh speakers. For example, in Kurukh, there is no equivalence for the Hindi word 'sari'; likewise, Kurukh has no equivalence for the English word 'chair'. The speakers call it either 'chair' or '/kursi:/' in Hindi. The reason behind this could be that the tribe does not have the concept of 'chair' in their language. For sitting they used mat, /pi:d'a:/ or /pi:nda:/.

The present Kurukh language has added new words to its vocabulary from its neighbouring dominant languages, which are evident in the speech of its community speakers. The above graph shows:

i. The percentage of code mixing in the male speakers of urban area is higher than that of rural area.

The male speakers, living in urban area, speak Kurukh in home domain (partially and often). Their working in different places leads to their continuous interactions with different people from different community groups. Preferably the interactions are done in Hindi, English or in Sadri languages. Whereas, the rural speakers are concerned with agriculture and farming. Their social gatherings, mostly with their own community members, results in less interaction with others as compared to the urban speakers. 
ii. The percentage of code mixing in the female speakers of urban area is higher than that of the rural area.

The female urban speakers are students, working ladies or housewives. The first two are in the continuous interaction with the members of other community. The last one is exposed to the performance of household duties, meeting neighbours, friends and watching television. It leads to affect their mother tongue as well. On the other side, the female speakers of rural areas watch television but their speech performances are less affected with it. They use Kurukh in home domain as well as in social domain.

iii. In rural area, the percentage of code mixing in male speakers is more than the female speakers.

The male speakers work at the fields (those who are farmers), some of them are selfemployed, labourers. They interact mostly with the speakers of other community as compared to female speakers of the rural area.

iv. In the urban area the percentage of code mixing in male speakers is more than in the female speakers.

The same happens in the case of male- female urban speakers. The female speakers are less exposed to the outside world than that of the male speakers, which ultimately reflect in their speech performances.

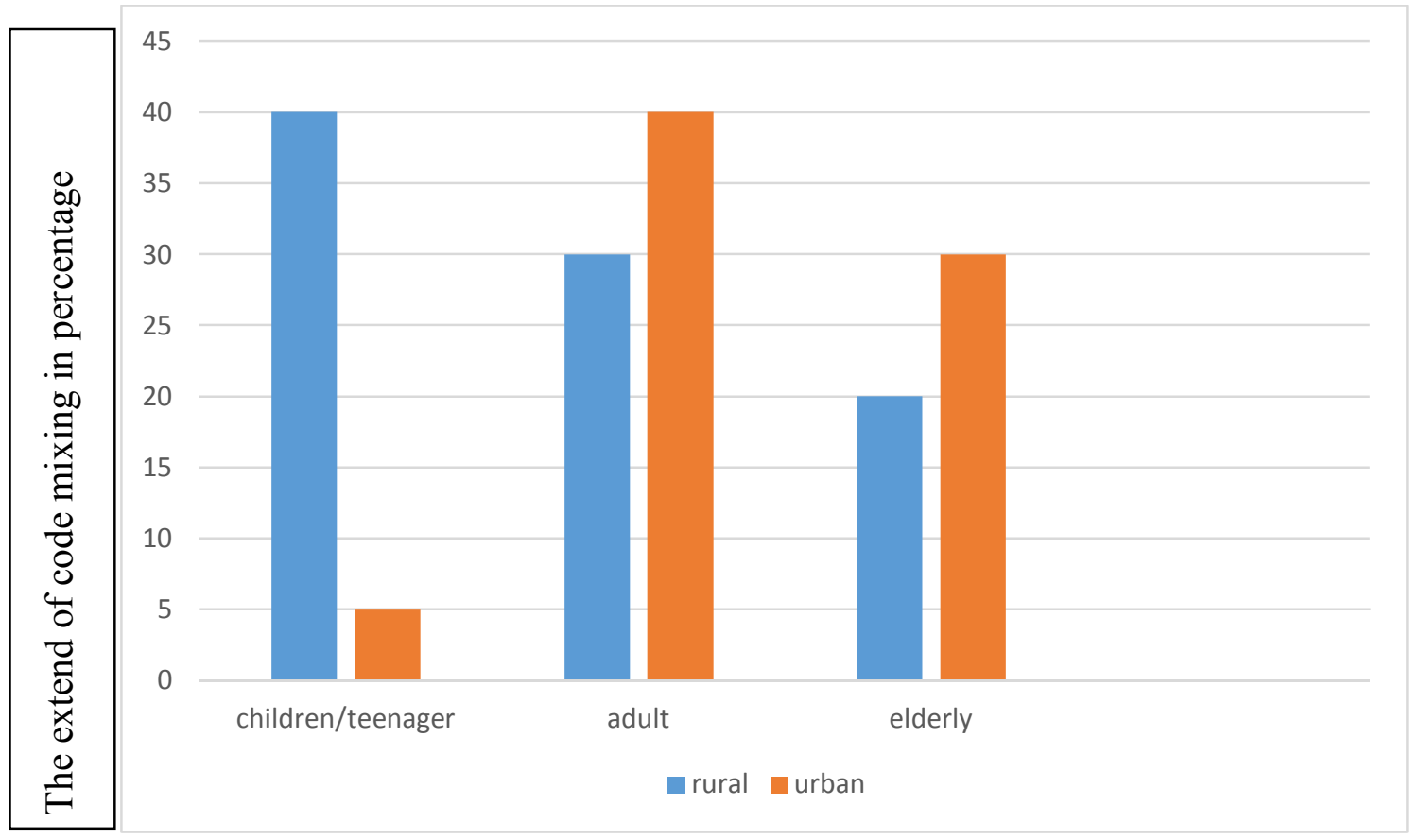

Fig. 3. The speech performance of different age groups in urban and rural social space.

On the basis of age, the above graph distinguishes the speakers into three groups: 'children and teenager' participants between the age of 5-17, 'adult' participant between the age 18-45, and 'elderly' participant above 45 years. Further classification of the speakers is based on their urban and rural social space.

The above graph shows the extent of code-mixing in teenagers, adults and elder participants of urban and rural areas: 
i. The code-mixing of the children and the teenagers of rural area is more than the code mixing of the adult and the elderly of rural area. When data were collected from the children and the teenagers, it was found that their exposure with other speech communities in schools reflects in their speech. 'Tolong Siki' (script) is introduced in some selected schools of Mandar, in Mandar College and in Tribal Department of Ranchi University. The code of conduct in the village schools is Hindi and sometimes Sadri; whereas, the code of conduct in cities is English and Hindi (Private and Government Schools).

ii. The code-mixing of the children and the teenagers of urban area is less than that of the adult and the elderly because there are limited speakers of that age group (5-17). The young urban speakers do not use the language in all domain. When the researcher reached the speakers, some could barely speak the language with proficiency. It was difficult for the researcher to get proper data from that age group.

iii. The code-mixing of rural adult speakers is higher than the code-mixing of elderly speakers. The adult speakers who are students, workers, have migrated to different cities for work, does not use the language in all domains. But the elderly above 45 who are farmers and retired officers, are less exposed to the multilingual society. So the code-mixing is less in elders.

iv. The code-mixing of an urban adult is higher than the code-mixing of an elderly.This kind of situation is found in both the rural and urban areas. The elders are less exposed than the adults of the community members. The adults interact with different groups of people for various purposes like for studies, jobs, social and religious gatherings with different groups. Here, two things are noticeable: first, the cultural chants, folklores are still practiced without any code-mixing; second, the religious gatherings and practices are done in Hindi and English. The Oraons follow Hindu and Christian religions and some are pagan worshippers. The words like Easter, Christmas, Christmas tree, Pope, Father, Church, and communion are some of the words of English which are used by the Oraon tribe.

v. The code mixing of an urban adult is more than a rural adult. The urban adults are more exposed to technology, cyber world, job-related works, meetings, trainings, and interacting and dealing mostly with Hindi Speaking communities. The rural adults live in a Kurukh speaking environment, so their code-mixing is less than the urban adults.

vi. The code-mixing of the urban elderly is more than the rural elderly. The elder people of urban area are not in a continuous practice with their language. Their speech is hindered because of the interactions with other groups, by watching Television programs, by listening to the songs, by using Smartphones, by watching movies etc.

\section{Conclusion}

The study describes the endangerment of Kurukh language by placing the language on each factor and scale defined by UNESCO on endangered languages. It is also intended to provide the pattern and extent of code-mixing in the speech of the rural and urban community members. Clearly, the speakers appearing in rural and urban environments have differences in their speech performances within their own community and with other communities. The difference in the 
speech performances also depends upon the gender and age factor, their exposure to different communities, and on different domains.

The study has its limitations. It is restricted only to Ranchi and its adjacent villages where they are co-existing with other tribes and dominant groups. If the research would have extended to the Oraon residing hub (Gumla and Rourkela), the results would have differed.

\section{Acknowledgements}

This work is supported and co-operated by the Oraon community speakers of Ranchi, Mandar, Itki, and Kadge. I am grateful to each one of them for their time and patience. A humble thank to my supervisor Dr. Md. M. Rahman for his guidance. I express my special thanks to Dr. R. K. Singh, Dr. Rajni Singh and Dr. Devaraj P. for their continuous support and suggestions in the completion of this work.

\section{References}

\section{Primary Sources}

Abbi, Anvita. (2012). Languages of India and India as a Linguistic Area. New Delhi. Print.

Andronov, Mikhail Sergeevich. (1970). Dravidian Languages. Nauka Publishing House. Print.

Benedikter, T. (2009). Language Policy and Linguistic Minorities in India. Berlin. Print.

Krishnamurti, Bhadriraju. (2003). The Dravidian languages. Cambridge: Cambridge Press. Print.

Mishra, Awadhesh Kumar. Word Formation in Kurukh (Oraon): A Study of Linguistic Typology and Language Change. Thesis. Jawaharlal Nehru University, New Delhi, 1991. Print.

Roy, S. C. (1984).The Oraons of Chotanagpur. Ranchi: Crown Publication. 38-39. Print.

Roy, S. C. (2012). Oraon Religion and Customs. New Delhi: Gyan Publishing house. Print.

Tirkey, Mahli Livins. (2013). Tribal Origins and Culture. New Delhi: Bosco Society for Printing and Graphic Training. 20-22. Print.

\section{Secondary Sources}

Chapter II Theories and Concepts in Sociolinguistics. (n.d.). Retrieved January 25, 2017, from https://tinyurl.com/ycgf4z7n

Bernard, H. (1992). Preserving Language Diversity. Human Organization, 51(1), 82-89. doi:10.17730/humo.51.1.bp4765g377932761

Dattamajumdar, S. (2008). Exploring Ethnolinguistic Vitality: A Case Study of Lepchas in Dzongu Valley. Language in India,8(7). Retrieved September 7, 2016.

Endangered Languages. (February). Retrieved August 24, 2016, from http://www.ethnologue.com/endangered-languages

Evans, L. (2011, April 15). Endangered languages: the full list. Retrieved August 24, 2016, from https://www.theguardian.com/news/datablog/2011/apr/15/language-extinct-endangered

Giles, H., Richard, Y. B., \& Donald, M. T. (1977). Towards a Theory of Language in Ethnic Group Relations. Language, Ethnicity and Intergroup Relations, ed. by Howard Giles, 307-348. 
Hale, K. (1998). On Endangered Languages and the Importance of Linguistic Diversity. Endangered languages, 192-216. doi:10.1017/cbo9781139166959.009

Landweer, M. L. (n.d.). Indicators of Ethnolinguistic Vitality. Retrieved December 7, 2016, from http://www.sil.org/sociolx/ndg-lg-indicators.html

Language Attitudes. (2012, September 28). Retrieved September 6, 2016, from https://www.sil.org/languageassessment/language-attitudes

Language Contact. (2012, September 27). Retrieved September 6, 2016, from https://www.sil.org/languageassessment/language-contact

Language endangerment. (n.d.). Retrieved August 24, 2016, from http://languagesindanger.eu/book-ofknowledge/language-endangerment/

Language Use. (2012, September 28). Retrieved September 6, 2016, from https://www.sil.org/languageassessment/language-use

Language Variation. (2012, September 28). Retrieved September 6, 2016, from https://www.sil.org/languageassessment/language-variation

Language Vitality and Endangerment - UNESCO. (n.d.). Retrieved January 9, 2016, from

https://tinyurl.com/ycngo7pk

Language Vitality. (2012, September 28). Retrieved September 6, 2016, from https://www.sil.org/languageassessment/language-vitality

Meyerhoff, M. (2006). Introducing Sociolinguistics. Routledge.

Milroy, L., \& Gordon, M. (2006). Sociolinguistics: Method and Interpretation. Malden: Blackwell.(n.d.). Retrieved August 7, 2016, from https://tinyurl.com/yag25sgz

Saba, Naheeb. Linguistic Heterogeneity and Multilinguality in India: A Linguistic Assessment of Indian Language Policies. Thesis. Aligarh Muslim University, Aligarh, 2011. N.p.: n.p., n.d. Print.

Sallabank, J. (2010). Language Endangerment: Problems and Solutions. ESharp. Retrieved March 4, 2017, from http://www.gla.ac.uk/esharp

Sankoff, D. (n.d.). Sociolinguistic Method and Linguistic Theory. Retrieved January 25, 2017, from https://tinyurl.com/yd52d $78 \mathrm{f}$

Shapiro, M. C., \&Schiffman, H. F. (n.d.). Language and Society in South Asia. Final Report. (Rep.). (ERIC Document Reproduction Service No. ED127806)

UNESCO Project: Atlas of the Worlds Languages in. (n.d.). Retrieved Aug. \&sept., 2016from https://tinyurl.com/yagrygg9

Wardhaugh, R. (2006). An Introduction to Sociolinguistics. Malden, MA, USA: Blackwell.

\section{Web Sources}

Geographical Dimension of Oroans. N.p., n.d. Web. 6 July 2017.

"Kurux." Ethnologue. N.p., n.d. Web. 6 July 2017.

Alisha Vandana Lakra is a Doctoral Research Fellow in English discipline at Indian Institute of Technology (ISM) Dhanbad, Jharkhand (India). She is presently working on A Descriptive Study of the Kurukh Language Spoken in and around Ranchi under Dr. Md. Mojibur Rahman. She pursued her M.Phil in English Literature under the guidance of Dr. Md. Mojibur Rahman from Indian 
Institute of Technology (ISM) Dhanbad, Jharkhand (India). Her area of interest is 'Descriptive Study', 'Documentation' and 'Applied Linguistics'.Email: lishnish3@gmail.com.

Md. Mojibur Rahman is Associate Professor and Head of the Department of Humanities and Social Sciences, Indian Institute of Technology (Indian School of Mines), Dhanbad, Jhakhand (India). He has twelve years of experience in teaching English Language Skills to the students of Science and Technology. His areas of interest include: ESP, EST, ELT, Language Testing, Translation Studies, Language Studies and Communication Skills Development. He has edited two books and published 25 research papers in several national and international journals and contributed chapters to various books of language and literature practices. He has also published book reviews. Email: mrahmanelt@gmail.com. 